\title{
Status of the world's smallest mammal, the bumble-bee bat Craseonycteris thonglongyai, in Myanmar
}

\author{
Maria João Ramos Pereira, Hugo Rebelo, Emma C. Teeling, Stephen J. O’Brien, lain Mackie, Si Si Hla Bu, \\ Khin Maung Swe, Khin Mie Mie and Paul J.J. Bates
}

\begin{abstract}
The bumble-bee bat Craseonycteris thonglongyai of the monospecific family Craseonycteridae is categorized as Endangered on the IUCN Red List. First discovered in 1973, it was until recently only known from a small population of approximately 2,300 individuals restricted to the catchment area of the River Kwai, Thailand. However, in 2001 a single craseonycterid was discovered in Mon State, Myanmar, extending its geographical range by approximately $250 \mathrm{~km}$. In October and November 2002 a survey was undertaken to examine the status of $C$. thonglongyai in Myanmar and assess its geographical distribution and population size. C. thonglongyai calls were recorded from bats emerging from nine of 19 caves surveyed; the population size was estimated to be 1,500 . The phylogenetic relationships
\end{abstract}

between the Thai and Myanmar populations were investigated using molecular, morphological and acoustic data. Morphologically, the two populations are indistinguishable. However, there is an $8-10 \mathrm{kHz}$ echolocation call divergence between the populations. Cytochrome $b$ data suggest that the two populations are similar and that the Myanmar population may be monophyletic. Annual surveys of the known bat roosts and in situ education programmes for local people are recommended together with the establishment of an integrated, transboundary Myanmar/Thai conservation strategy.

Keywords Bumble-bee bat, Craseonycteris thonglongyai, Chiroptera, cytochrome b, distribution, echolocation, genetics, Myanmar.

\section{Introduction}

The bumble-bee bat Craseonycteris thonglongyai (Hill, 1974) is considered to be the world's smallest mammal and is categorized as Endangered on the IUCN Red List (Hutson et al., 2001; IUCN, 2006). Until recently it was thought to be restricted to the catchment area of the River Kwai in Thailand (Duangkhae, 1991) because

\footnotetext{
Maria João Ramos Pereira Centro de Biologia Ambiental, Departamento de Biologia Animal, Faculdade de Ciencias de Lisboa, Edificio C6, 6.3.40, Campo Grande, 1749 - 016 Lisboa, Portugal.

Hugo Rebelo CIBIO, Universidade do Porto, Campus Agrário do Vairão, 4485661 Vairão, Portugal.

Emma C. Teeling Department of Zoology, University College Dublin, Belfield, Dublin 4, Ireland.

Stephen J. O'Brien The Laboratory of Genomic Diversity, National Cancer Institute, Frederick, Maryland 21702, USA.

Iain Mackie Department of Zoology, University of Aberdeen, Tillydrone Avenue, Aberdeen, AB24 2TZ, UK.

Si Si Hla Bu, Khin Maung Swe and Khin Mie Mie Zoology Department, University of Yangon, Yangon, Myanmar.

Paul J. J. Bates (Corresponding author) Harrison Institute, Bowerwood House, St Botolph's Road, Sevenoaks, Kent TN13 3AQ, UK

E-mail hzm@btinternet.com

Received 12 May 2005. Revision requested 22 September 2005. Accepted 30 March 2006.
}

surveys of apparently suitable areas elsewhere in Thailand had not located this species (Hutson et al., 2001).

In 2001 a single individual of $C$. thonglongyai was captured at a cave in a limestone outcrop on the flood plain of the Thanlwin River (=Salween River) in Mon State, Myanmar. This significantly extended the known range of the species (Bates et al., 2001). From a conservation viewpoint, a detailed study of the status of the apparently allopatric Myanmar population and its relationship with the Thai population was of considerable interest.

The five principal objectives of the study were to locate Craseonycteris roosting sites in the limestone outcrops of Kayin and Mon States in south-east Myanmar, determine the size of the colonies at each cave site, characterize the population with respect to morphometry and echolocation, undertake a genetic study of the population using DNA analysis, and determine the threats to, and make recommendations for, the protection of the most important roosting sites.

\section{Methods}

\section{Survey}

Nineteen caves in limestone outcrops in the vicinities $(<40 \mathrm{~km})$ of the towns of Hpa-an, Kayin State and 
Mawlamyine, Mon State (Fig. 1) were surveyed during October and November 2002. During daylight hours the caves were inspected for the presence of bats. From 17.30 (before sunset) to 19.30 (post sunset), bat echolocation detectors were used to determine the presence of craseonycterids among the emerging bats. Two bat detectors with time expansion technology (a Pettersson D240x; Pettersson Elektroniks, Uppsala, Sweden), and a Tranquility II (David Bale, Cheltenham, UK) were used to record simultaneously the echolocation calls of bats emerging from each cave entrance. The calls were stored on a mini-disc recorder and a digital audio player (DAP) recorder (file recorded in WAV format with a sampling rate of $44.1 \mathrm{kHz}$ ).

Craseonycteris were caught with a mist net and harp trap at the entrance to one cave. A flip net was used to capture bats at two caves. Colony sizes were estimated by visually counting emerging bats. This methodology seems to be reliable for Craseonycteris because they appear a few minutes before dusk, have a distinctively small size, and a characteristic echolocation call (Duangkhae, 1991).

\section{Handling procedures}

Upon capture, weight and forearm length were recorded. To minimize stress from handling two skin biopsies of $3 \mathrm{~mm}$ in diameter were taken from the wings of only 11 individuals, according to the procedure of Worthington Wilmer \& Barratt (1996). The samples were stored in $70 \%$ ethanol. With the exception of three individuals taken as voucher specimens for taxonomic study, all individuals were released.

\section{Echolocation characterization}

Echolocation calls were recorded after the bats were released, using a D-240x ultra sound detector and a DAP recorder. Bats were visually followed and echolocation calls were recorded in open areas so that their calls would be representative of search phase echolocation. Feeding calls were also recorded. These recordings were used as reference for comparison with others made during the cave survey. Subsequent analysis was carried out using Bat Sound 3.31 (Pettersson Elektroniks,

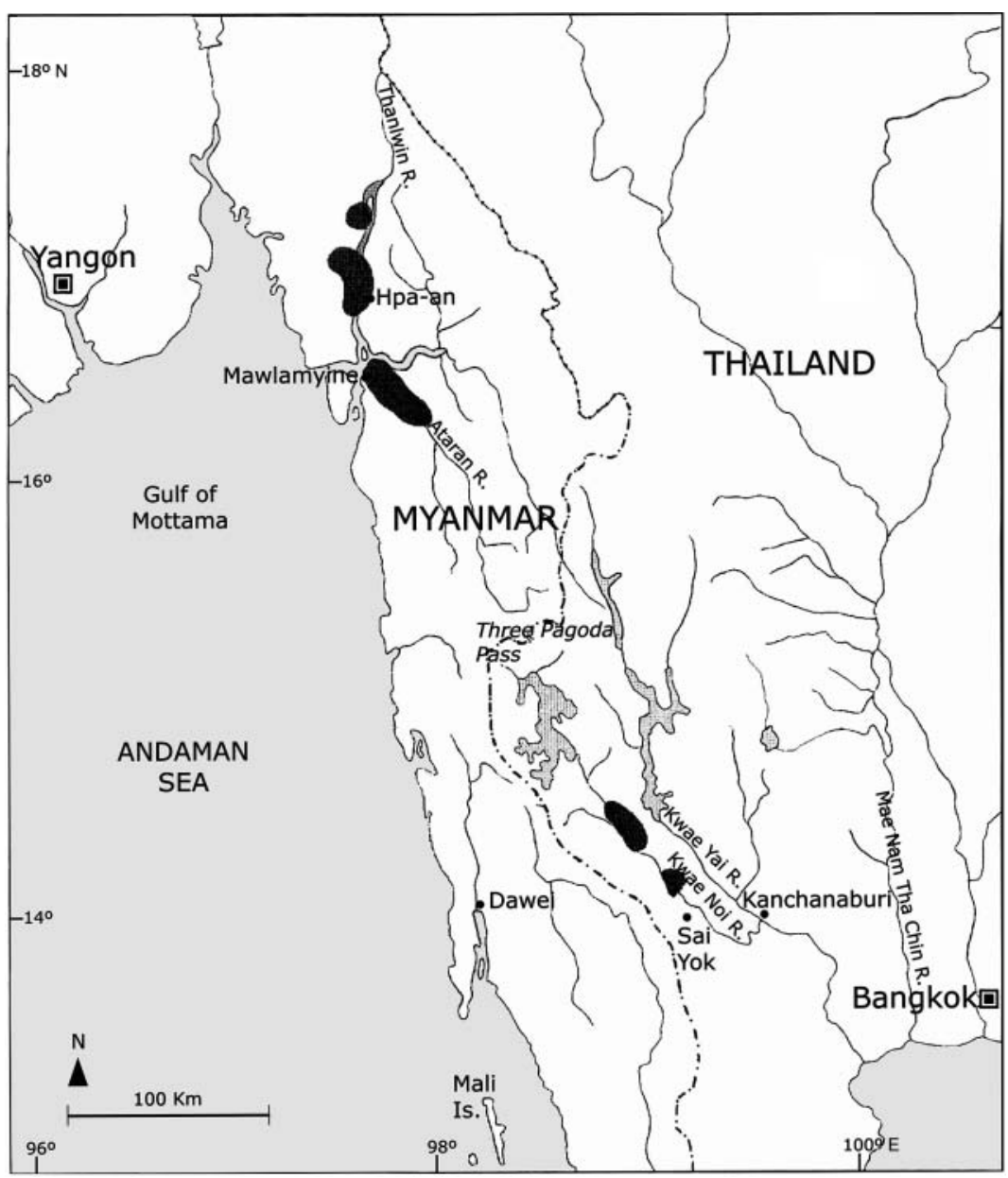

(c) $2006 \mathrm{FFI}$, Oryx, 40(4), 456-463
Fig. 1 Known distribution (dark shaded areas) of C. thonglongyai in Myanmar and Thailand. 
Uppsala, Sweden) using methods described in Kalko \& Schnitzler (1989).

\section{Morphometrics and specimen collection}

Four individuals were used in a detailed morphological study. One was collected in March 2001 (Bates et al., 2001) and three in November 2002. All were subsequently deposited either at the University of Yangon, Myanmar, or the Harrison Institute, UK. Twenty-five external, cranial and dental measurements (Appendix) were taken from the voucher specimens using digital callipers.

\section{Genetic analysis}

Genomic DNA was extracted from the biopsy punches using the Qiagen DNesay tissue kit. Four hundred and two base pairs from the $5^{\prime}$ end of the cytochrome $b$ mitochondrial gene were amplified and sequenced for each individual using MVZ04 and MVZ05 primers (Smith \& Patton, 1991) following methods detailed in Murphy et al. (2001). Published cytochrome b sequences for members of the superfamily Rhinolophoidea (sensu Teeling et al., 2005), a Thai craseonycterid and for four pteropodid species (outgroups) were included in the analyses. The data set was aligned using ClustalX (Thompson et al., 1997) and further modified in SE-AL (Rambaut, 1996). All species and GenBank accession numbers are listed in Table 1.

With the exception of Bayesian analyses all phylogenetic methods were performed using PAUP* $4.0 b 10$

Table 1 Genbank accession numbers.

\begin{tabular}{ll}
\hline Species & Accession number \\
\hline Cynopterus brachyotis & AB046321 \\
Nyctimene robinsoni & AF144066 \\
Pteropus rufus & AB085732 \\
Rousettus amplexicaudatus & AB046329 \\
Rhinopoma hardwickii & AY056462 \\
Megaderma spasma & AY057942 \\
Rhinolophus cornutus & AY141041 \\
Rhinolophus ferrumequinum & AB085731 \\
Rhinolophus hipposideros & AY141040 \\
Rhinolophus perditus & AY141039 \\
Aselliscus stoliczkanus & AF451336 \\
Hipposideros armiger & AF451332 \\
Hipposideros bicolor & AF451335 \\
Hipposideros larvatus & AF451333 \\
Hipposideros pratti & AF451334 \\
C. thonglongyai (Thailand) & AF512008 \\
C. thonglongyai (Myanmar)-Type1 & EF035011* \\
C. thonglongyai (Myanmar)-Type2 & EF035012* \\
\hline
\end{tabular}

*sequences new to this study
(Swofford, 2003) and included Maximum Likelihood (ML), Minimum Evolution (ME), and Maximum Parsimony (MP). Bayesian analyses were carried out with MrBayes $3.0 b 4$ (Huelsenbeck \& Ronquist, 2001). ML analyses incorporated the GTR $+\Gamma+\mathrm{I}$ model of sequence evolution as suggested by ModelTest (Posada \& Crandall, 1998); base frequencies $=(0.31620 .3962$ $0.11380 .1738) ; \mathrm{R}$ matrix $=\left(\begin{array}{l}6.088627 .5234 \\ 5.64460 .4807\end{array}\right.$ 67.9956); shape parameter of the gamma distribution = 1.3970; proportion of the invariant sites $=0.5581$. ML analyses were also completed with third positions removed. In ML and ME bootstrap analyses the starting tree was obtained via neighbour-joining. ME analyses were performed with ML distances corrected according to the GTR $+\Gamma+\mathrm{I}$ model of sequence evolution. Bootstrap analyses included 100 replications with ML and 500 replications with ME and MP. Heuristic searches with tree-bisection and reconnection branch-swapping for all analyses were used. Bayesian posterior probabilities were calculated using a Markov chain Monte Carlo sampling approach incorporated in MrBayes 3.0b4. Bayesian analyses used the general time reversible (GTR) model of sequence evolution with an allowance for a gamma distribution of rates $(\Gamma)$ and a proportion of invariant sites (I). Starting trees were random, four simultaneous Markov chains were run for 1 million generations, burn-in values were set at 50,000 generations, and trees were sampled every 20 generations.

\section{Results}

\section{Distribution and colony size}

C. thonglongyai were located at nine cave sites, i.e. $47.4 \%$ of the caves surveyed (Fig. 1; details of the caves are omitted to minimize the possibility of future disturbance). At seven sites echolocation calls were recorded outside the cave entrance. Additionally, at two sites, individuals were collected within the caves. At one of these, a flip net was used, which captured three bats. Subsequent trapping at dusk inside the cave entrance, using a mist net and a harp trap, yielded many more individuals. At the other site, a single individual was captured using a flip net. However, a harp trap and mist nets set within the cave failed to catch further individuals.

The population size in this region was estimated to be c. 1,500 individuals. First emergence time was $17.35 \pm$ SD 4 minutes $(\mathrm{n}=11)$, with individuals of C. thonglongyai returning to the roost $31 \pm \mathrm{SD}$ 7 minutes $(n=11)$ after emergence, thus showing a very short dusk activity period. The use of ultrasound detectors confirmed the presence of this species at nine caves. 


\section{Morphology}

Individuals of $C$. thonglongyai caught in the field weighed on average $2.4 \pm$ SD $0.2 \mathrm{~g}(\mathrm{n}=14)$ and had a forearm length of $24.1 \pm$ SD $0.87 \mathrm{~mm}(\mathrm{n}=14)$. Twenty-five external, cranial and dental measurements taken from the voucher specimens were compared to those from 26 specimens from Thailand (Hill, 1974). All, except ear length, were essentially similar, with little difference in mean values and an overlap in the ranges (Tables 2 \& 3). A comparison of the Myanmar material with specimens from Thailand in the Natural History Museum, London, UK, showed that the apparent difference in the ear length was a result of differences in measuring techniques. On the dentition Hill (1974) wrote that the lower canine had 'no accessory cusps' and illustrated it as such. However, an examination of the 17 skulls of Thai specimens in the Natural History Museum, London, and the four skulls from Myanmar revealed that anterior and posterior cingular cusps were always present. This confirms that there are no apparent morphological or morphometric differences between the two populations and supports the view of Bates et al. (2001).

\section{Echolocation}

The echolocation call of $C$. thonglongyai from the Myanmar study site (Fig. 2) is clearly distinct from that of the Thailand population (Surlykke et al., 1993). Table 4 presents descriptor variables of the species' echolocation calls. The difference in the peak frequency between Myanmar and Thailand (Surlykke et al., 1993) is approximately $8-10 \mathrm{kHz}$. Our data suggest that there may be differences in the bandwidth, pulse duration and interval between pulses but these results are based on small sample sizes and must be verified by future studies. C. thonglongyai recordings are available on request from MJRP.

Table 2 Eleven external measurements ( $\mathrm{mm}$ ) and body mass $(\mathrm{g}$ ) of $C$. thonglongyai (for abbreviations, see Appendix). Minimum-maximum values are given where $n \geqslant 2$; sample sizes differing from those reported under $\mathrm{n}$ are given in parentheses.

\begin{tabular}{|c|c|c|c|c|c|c|c|c|c|c|c|c|c|}
\hline & $\mathrm{n}$ & FA & $\mathrm{III}^{\mathrm{M}}$ & $\mathrm{III}^{1}$ & $\mathrm{III}^{2}$ & $\mathrm{IV}^{\mathrm{M}}$ & $\mathrm{IV}^{1}$ & $\mathrm{IV}^{2}$ & $\mathrm{~V}^{\mathrm{M}}$ & TIBIA & $\mathrm{HF}^{2}$ & E & MASS \\
\hline \multicolumn{14}{|l|}{ Myanmar } \\
\hline (males) & 3 & 24.6 & $20.7(2)$ & $7.0(2)$ & $20.4(2)$ & $22.5(2)$ & $4.0(2)$ & $9.6(2)$ & $22.5(2)$ & 12.7 & $6.2(2)$ & 11.0 & 2.3 \\
\hline & & $24.5-24.7$ & $20.7,20.7$ & $6.7,7.2$ & $20.3,20.5$ & $22.3,22.7$ & $3.7,4.3$ & $8.9,10.3$ & $22.1,22.8$ & $12.4-13.1$ & $6.1,6.2$ & $10.5-11.4$ & $2.0-2.5$ \\
\hline $\begin{array}{l}\text { Myanmar } \\
\text { (female) }\end{array}$ & 1 & 25.8 & 21.2 & 7.0 & 21.2 & 23.6 & 4.1 & 11.0 & 23.4 & 12.8 & 6.0 & 11.2 & 2.6 \\
\hline \multicolumn{14}{|l|}{ Thailand } \\
\hline & & $24.1-25.2$ & $19.8-21.6$ & $6.4-7.0$ & $18.7-21.5$ & $21.7-23.2$ & $3.5-4.2$ & $9.7-10.7$ & $21.7-23.0$ & $11.9-12.9$ & $5.9-6.8$ & $9.0-10.0$ & \\
\hline \multicolumn{14}{|l|}{ Thailand } \\
\hline$(\text { females })^{1}$ & 9 & 24.9 & 21.1 & 6.8 & 20.1 & 23.1 & 3.9 & 10.3 & 23.2 & 12.3 & 6.2 & 9.8 & \\
\hline & & $22.5-25.8$ & $19.7-21.7$ & $6.5-7.1$ & $19.4-21.2$ & $21.7-23.8$ & $3.6-4.3$ & $9.7-10.8$ & $21.8-23.7$ & $11.7-12.8$ & $5.8-6.6$ & $9.0-10.2$ & \\
\hline
\end{tabular}

${ }^{1}$ After Hill (1974)

${ }^{2}$ Includes claw

Table 3 Fourteen cranial and dental measurements (in $\mathrm{mm}$ ) of $C$. thonglongyai (for abbreviations, see Appendix). Minimum-maximum values are given where $\mathrm{n} \geqslant 3$; sample sizes differing from those reported under $\mathrm{n}$ are given in parentheses.

\begin{tabular}{|c|c|c|c|c|c|c|c|c|c|c|c|c|c|c|c|}
\hline & $\mathrm{n}$ & GTL & CCL & ZB & BB & $\mathrm{BH}$ & PC & TBL & TBW & BW & $\mathrm{C}-\mathrm{M}^{3}$ & $\mathrm{M}^{3}-\mathrm{M}^{3}$ & $\mathrm{C}^{1}-\mathrm{C}^{1}$ & $\mathrm{C}-\mathrm{M}_{3}$ & MDL \\
\hline $\begin{array}{r}\text { Myanmar } \\
\text { (males) }\end{array}$ & 3 & 10.8 & 9.7 & $5.8(2)$ & 5.5 & $4.2(2)$ & $2.2(2)$ & $2.6(2)$ & $2.0(2)$ & $0.7(2)$ & 3.8 & $4.6(2)$ & $3.1(2)$ & 4.3 & 7.2 \\
\hline & & $10.4-11.0$ & $9.4-10.1$ & $5.7,5.9$ & $5.4-5.7$ & $4.2,4.2$ & $2.2,2.2$ & $2.5,2.7$ & $1.9,2.0$ & $0.7,0.7$ & $3.6-3.9$ & $4.6,4.6$ & $3.0,3.1$ & $4.2-4.5$ & $7.0-7.3$ \\
\hline $\begin{array}{l}\text { Myanmar } \\
\text { (female) }\end{array}$ & 1 & 10.9 & 10.1 & & 5.7 & 4.3 & 2.2 & 2.5 & 2.0 & 0.7 & 3.8 & 4.8 & 3.1 & 4.4 & 7.2 \\
\hline $\begin{array}{l}\text { Thailand } \\
\text { (males)* }\end{array}$ & 12 & $\begin{array}{l}11.2(11) \\
10.6-11.5\end{array}$ & $\begin{array}{l}10.0 \\
9.9-10.1\end{array}$ & $\begin{array}{l}5.8 \\
5.5-6.0\end{array}$ & $\begin{array}{l}5.5 \\
5.3-5.7\end{array}$ & $\begin{array}{l}4.1 \\
4.0-4.3\end{array}$ & $\begin{array}{l}2.2 \\
2.1-2.3\end{array}$ & $\begin{array}{l}2.6 \\
2.4-2.7\end{array}$ & $\begin{array}{l}1.7 \\
1.5-1.9\end{array}$ & $\begin{array}{l}0.6 \\
0.5-0.7\end{array}$ & $\begin{array}{l}3.8 \\
3.7-3.9\end{array}$ & $\begin{array}{l}4.7 \\
4.6-4.9\end{array}$ & $\begin{array}{l}3.0 \\
2.9-3.2\end{array}$ & $\begin{array}{l}4.1 \\
4.0-4.2\end{array}$ & $\begin{array}{l}7.1 \\
7.0-7.3\end{array}$ \\
\hline $\begin{array}{l}\text { Thailand } \\
\text { (females)* }\end{array}$ & 5 & $\begin{array}{l}10.9 \\
10.3-11.1\end{array}$ & $\begin{array}{l}9.9 \\
9.6-10.0\end{array}$ & $\begin{array}{l}5.6 \\
5.5-5.7\end{array}$ & $\begin{array}{l}5.5 \\
5.4-5.5\end{array}$ & $\begin{array}{l}4.0 \\
3.9-4.0\end{array}$ & $\begin{array}{l}2.1 \\
2.1-2.2\end{array}$ & $\begin{array}{l}2.6 \\
2.3-2.6\end{array}$ & $\begin{array}{l}1.7 \\
1.6-1.8\end{array}$ & $\begin{array}{l}0.6 \\
0.5-0.6\end{array}$ & $\begin{array}{l}3.7 \\
3.6-3.8\end{array}$ & $\begin{array}{l}4.6 \\
4.5-4.6\end{array}$ & $\begin{array}{l}2.8 \\
2.8-2.9\end{array}$ & $\begin{array}{l}4.0 \\
3.9-4.0\end{array}$ & $\begin{array}{l}6.8 \\
6.7-6.9\end{array}$ \\
\hline
\end{tabular}

*After Hill (1974) 


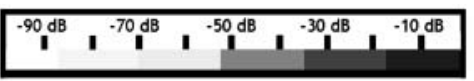

Spectogram FFT size 512 Hanning window - Right
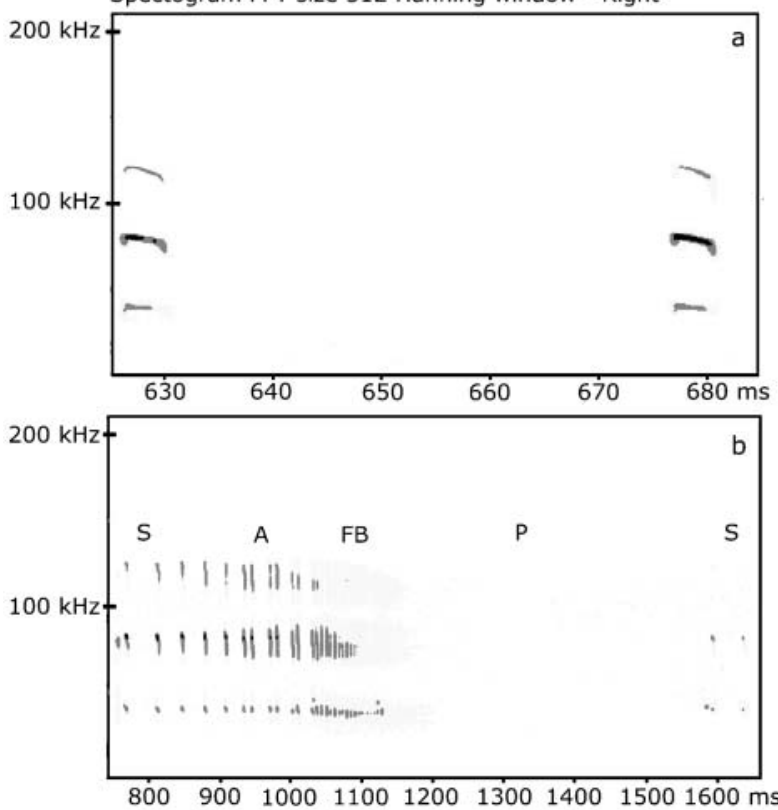

Fig. 2 Sonograms of examples of echolocation calls produced by $C$. thonglongyai from Myanmar: (a) two search phase echolocation calls, (b) a feeding buzz.

\section{Genetics}

The Craseonycteridae formed a monophyletic clade; the Thailand representative grouped with the Myanmar craseonycterids with $100 \%$ bootstrap support and a posterior probability of 1.000 . In 11 Myanmar craseonycterids only two haplotypes were found. One individual differed from all others by an A-G substitution at nucleotide position 394. The Myanmar population appeared to form a monophyletic clade and received moderate bootstrap support (71-81\% bootstrap support; posterior probability of 0.84 ), however only three substitution differences separated the Thai and Myanmar craseonycterids (T-C at position 223; G-A at position 343; C-T at position 390) and the branch length was short. The phylogenetic trees (Fig. 3) differed with and without the inclusion of third positions, which have been shown to be saturated (Hulva \& Horacek, 2002).
The optimal topology resulting from analyses without third positions is more similar to the topology reported in Teeling et al. (2005), in which they investigated the interfamilial relationships within Chiroptera with a $13 \mathrm{~kb}$ nuclear gene data for representatives of all bat families.

\section{Discussion}

This study confirms the suggestion of Bates et al. (2001) that $C$. thonglongyai may be distributed widely amongst the limestone outcrops of the flood plains of the Thanlwin, Ataran (and Gyaing) Rivers in Kayin and Mon States, Myanmar. Originally known from one cave (Bates et al., 2001), it has now been recorded from nine separate sites that extend $102 \mathrm{~km}$ from north to south. Unfortunately, we were not able to survey all the potential geographical range. In future, if the security situation permits, it would be of value to explore other areas adjacent to the Thanlwin and Ataran Rivers that are known to have extensive limestone outcrops (Foley, 1836; Tickell \& Parish, 1859).

However, although only a small proportion of the potential caves within the study area were surveyed, the population size is two-thirds of that cited for Thailand or some $40 \%$ of the known world population of 3,800 individuals. The number of individuals in some of the caves (600-800) was also high when compared to numbers estimated in Thailand (a maximum of 560 individuals; Duangkhae, 1991).

Currently, the C. thonglongyai population in Myanmar does not appear to be greatly threatened. Potential future threats are the extraction of limestone for cement production, pollution, and human disturbance. At present no known locality of $C$. thonglongyai is directly affected by limestone extraction but there is pollution, in the form of smoke and dust, generated by two local cement factories within the bats' foraging area (Bates, 2001). Meanwhile, a number of the caves at which $C$. thonglongyai was recorded are Buddhist sites attracting a growing number of pilgrims. Although most pilgrims do not penetrate deep into the caves, they do have an impact on the temperature, humidity, light and noise levels of the cave environment and could provoke $C$. thonglongyai to abandon its roost. Human disturbance

Table 4 Descriptor variables (mean \pm SD) of the echolocation calls of $C$. thonglongyai from Myanmar and Thailand. Sample size is for the number of individual bats sampled.

\begin{tabular}{|c|c|c|c|c|c|c|c|c|}
\hline Population & $\begin{array}{l}\text { Peak } \\
\text { frequency } \\
(\mathrm{kHz})\end{array}$ & $\begin{array}{l}\text { Maximum } \\
\text { frequency } \\
(\mathrm{kHz})\end{array}$ & $\begin{array}{l}\text { Minimum } \\
\text { frequency } \\
(\mathrm{kHz})\end{array}$ & $\begin{array}{l}\text { Band } \\
\text { width } \\
(\mathrm{kHz})\end{array}$ & $\begin{array}{l}\text { Pulse } \\
\text { duration } \\
(\mathrm{ms})\end{array}$ & $\begin{array}{l}\text { Interval } \\
\text { between } \\
\text { pulses (ms) }\end{array}$ & $\begin{array}{l}\text { Sweep } \\
\text { rate } \\
(\mathrm{kHz} / \mathrm{ms})\end{array}$ & $\begin{array}{l}\text { Duty } \\
\text { cycle (\%) }\end{array}$ \\
\hline Myanmar $(\mathrm{n}=19)$ & $81.78 \pm 0.91$ & $85.04 \pm 1.44$ & $70.69 \pm 1.41$ & $14.35 \pm 3.22$ & $3.68 \pm 0.33$ & $54.19 \pm 7.92$ & $3.95 \pm 0.87$ & $6.89 \pm 0.86$ \\
\hline Thailand $(\mathrm{n}=4)$ & $73.2 \pm 0.4$ & & & $12 \pm 4$ & $3.5 \pm 0.4$ & $45.45 \pm 10.89$ & & \\
\hline
\end{tabular}


(a)

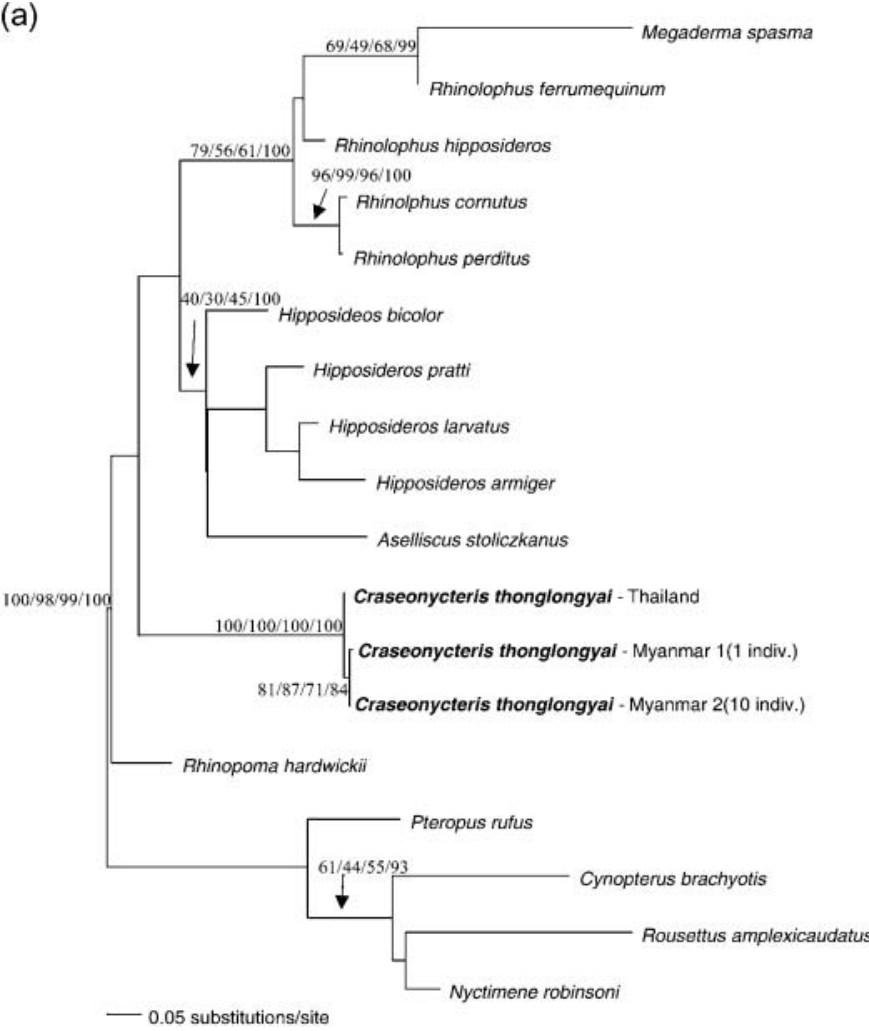

(b)

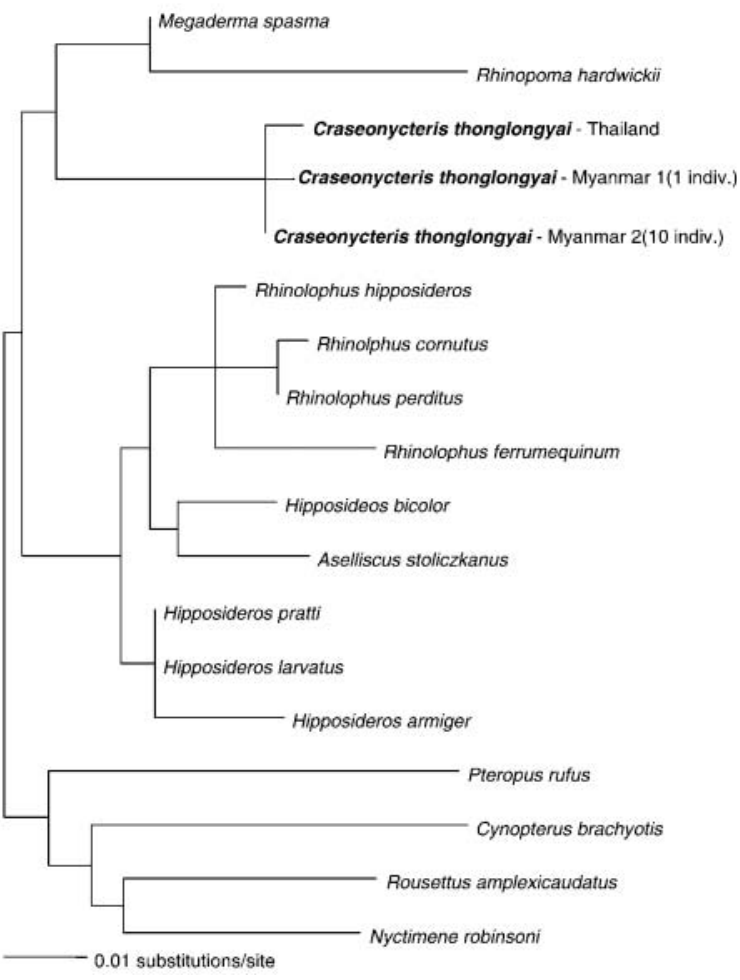

Fig. 3 Phylogenetic trees for C. thonglongyai in Myanmar and Thailand and related and other species (see text for details): (A) The unrooted maximum likelihood (ML) tree for 402 base pairs of cytochrome $b$ under the GTR $+\Gamma+$ I model of sequence evolution (-ln likelihood $=2581.61)$. Numbers plotted along the branches indicate bootstrap values and Bayesian posterior probabilities shown as percentages in the following order: ML/ MP/ ME/ Bayesian. (B) The unrooted maximum likelihood (ML) tree for $268 \mathrm{bp}$ of cytochrome $b$ with third positions removed under the GTR $+\Gamma+\mathrm{I}$ model of sequence evolution $(-\ln$ likelihood $=800.5)$.

has led to caves being abandoned by $C$. thonglongyai in Thailand (Hutson et al., 2001). On the positive side, local monks restrict the hunting of bats within Buddhist caves.

It is still not clear whether the Myanmar and Thai populations are reproductively isolated. In terms of echolocation, the calls of the Myanmar population are clearly distinct, whereas morphologically they are similar. Currently, the taxonomic and evolutionary significance of this acoustic variation is not known. Information from other taxa suggests that geographical variation in peak frequency within species is not uncommon. Several examples of differences in excess of $10 \mathrm{kHz}$ are known from the Rhinolophidae (Csorba et al., 2003). In the case of C. thonglongyai a complete survey of the echolocation calls along a transect linking the known ranges in Myanmar and Thailand would provide information as to whether the variation is clinal or step-like, with two distinct acoustic populations.

The molecular phylogenetic analyses suggest that the Myanmar population may form a monophyletic clade. However, this needs to be confirmed through the collection of more samples. A more detailed study involving microsatellites is also desirable because of the faster mutation rate of these genetic markers and because bi-parentally inherited nuclear markers have been shown to support an alternative phylogenetic relationship, which cannot be observed using only maternally inherited mitochondrial DNA (Roca et al., 2004).

Based on this work our conservation recommendations, in accordance with the species action plan (Hutson et al., 2001) and tailored to the specific needs of the Myanmar population, are:

- Conduct further studies to determine whether the Myanmar and Thai populations are monospecific.

- Conduct an annual census of the known cave sites within Kayin and Mon States, with an assessment of threats.

- Conduct further surveys to establish distribution and population levels. Possible locations include: in Kayin State, the extensive limestone hills north of Yinbaing on the Thanlwin River (information based on Foley, 1836) and a vast limestone outcrop c. $30 \mathrm{~km}$ to the north-west of Three 
Pagoda Pass (information based on Tickell \& Parish, 1859); in Tanintharyi Division, a large limestone cave $33 \mathrm{~km}$ from the northern border of Sai Yok National Park (information from PJJB). Unfortunately, all three areas are currently offlimits because of security considerations.

- Conduct a local education programme to reinforce ideas about the positive value of bats, including $C$. thonglongyai, within the local community, to reduce disturbance at cave roosting sites.

- Minimize the impact of limestone extraction on cave roosts through dialogue with representatives of local cement factories.

- Assess the bats' diet and describe the insect population within the foraging areas.

- Study the population structure, behaviour, and echolocation calls of both the Myanmar and Thai populations.

To address and implement these recommendations a consortium of research scientists from University College Dublin, Ireland, Harrison Institute, UK, Prince of Songkla University, Thailand, and Yangon University, Myanmar, created a multinational Craseonycteris team, in November 2005, dedicated to the transboundary conservation of this species. Currently the consortium is completing extensive surveys throughout the species' range, examining the acoustic variation, roost preferences, population genetics and evolutionary history of the Thai and Myanmar craseonycterid populations. This information will be used to create long-term conservation management plans.

\section{Acknowledgements}

In Myanmar, we thank the Rector of the University of Yangon, Professor Dr Soe Yin, and Professor Dr Daw Tin Nwe and all the staff and students of the University's Zoology Department for their support and assistance. We would also like to thank Peter Scrimshaw and Colleen Mainstone for their assistance in the field. In the UK, we are grateful to Paula Jenkins of the Natural History Museum, London, Professor Paul Racey of Aberdeen University and Dr David Harrison and Malcolm Pearch of the Harrison Institute for their advice and assistance. We also thank Sebastien Puechmaille from University College Dublin, Ireland for helpful comments and suggestions on the manuscript. MJRP and HR were funded by the BP Conservation Programme and we are grateful to Marianne Dunn for her help in this respect. Valuable additional financial support was received from Total E\&P Myanmar and from the Darwin Initiative, UK. Federal funds were made available by the National Cancer Institute, National Institutes of Health, under Contract No. N01-CO-12400.

\section{References}

Bates, P.J.J. (2001) Conservation Status of the Bat and Bird Fauna of the Limestone Karst Areas of Kayin and Mon States, Myanmar (Burma). Unpublished Report for Fauna \& Flora International, Cambridge, UK.

Bates, P.J.J., Tin Nwe, Khin Maung Swe \& Si Si Hla Bu (2001) Further new records of bats from Myanmar (Burma), including Craseonycteris thonglongyai Hill 1974 (Chiroptera: Craseonycteridae). Acta Chiropterologica, 3, 33-41.

Csorba, G., Ujhelyi, P. \& Thomas, N. (2003) Horseshoe Bats of the World. Alana Books, Bishop's Castle, UK.

Duangkhae, S. (1991) Search for Kitti's hog nosed bat Craseonycteris thonglongyai in western Thailand. Natural History Bulletin of the Siam Society, 39, 1-17.

Foley, W. (1836) Notes on the geology, \&c. of the country in the neighbourhood of Maulamyeng (vulg. Moulmein). Journal of the Asiatic Society of Bengal (1836), 269-281.

Hill, J.E. (1974) A new family, genus and species of bat (Mammalia: Chiroptera) from Thailand. Bulletin of the British Museum of Natural History, 32, 29-43.

Huelsenbeck, J.P. \& Ronquist, F. (2001) MrBAYES: Bayesian inference of phylogenetic trees. Bioinformatics, 17, 754-755.

Hulva, P. \& Horacek, I. (2002) Craseonycteris thonglongyai (Chiroptera: Craseonycteridae) is a rhinolophoid: molecular evidence from cytochrome b. Acta Chiropterologica, 4, 107-120.

Hutson, A.M., Mickleburgh, S.P. \& Racey, P.A. (2001) Microchiropteran Bats: Global Status Survey and Conservation Action Plan. IUCN/SSC Chiroptera Specialist Group, IUCN, Gland, Switzerland and Cambridge, UK.

IUCN (2006) 2006 IUCN Red List of Threatened Species. IUCN, Gland, Switzerland [http://www.redlist.org, accessed 11 July 2006].

Kalko, E.K.V. \& Schnitzler, H.U. (1989) The echolocation and hunting behaviour of Daubenton's bat, Myotis daubentonii. Behavioral Ecology and Sociobiology, 24, 225-238.

Murphy, W.J., Eizirik, E., O’Brien, S.J., Madsen, O., Scally, M., Douady, C.J., Teeling, E., Ryder, O.A., Stanhope, M.J., de Jong, W.W. \& Springer, M.S. (2001) Resolution of the early placental mammal radiation using Bayesian phylogenetics. Science, 294, 2348-2351.

Rambaut, A. (1996) SE-Al Sequence Alignment Editor, version 1.0 a1. Department of Zoology, University of Oxford, Oxford, UK.

Roca, A., Georgiadis, N. \& O'Brien, S.J. (2004) Cytonuclear genomic dissociation in African elephant species. Nature Genetics, 37, 96-100.

Smith, M.F. \& Patton, J.L. (1991) Variation in mitochondrial cytochrome $b$ sequence in natural populations of South American akodontine rodents (Muridae: Sigmodontinae). Molecular Biology and Evolution, 8, 85-103.

Surlykke, A., Miller, L.A., Mohl, B., Andersen, B.B., Christensendalsgaard, J. \& Jorgensen, M.B. (1993) Echolocation in two very small bats from Thailand Craseonycteris thonglongyai and Myotis siligorensis. Behavioral Ecology and Sociobiology, 33, 1-12.

Swofford, D.L. (2003) PAUP*. Phylogenetic Analysis Using Parsimony (* and Other Methods). Sinauer Associates, Sunderland, USA. 
Teeling, E.C., Springer, M.S., Madsen, O., Bates, P.J.J., O'Brien, S.J. \& Murphy, W.J. (2005) A molecular phylogeny for bats illuminates biogeography and the fossil record. Science, 307, 580-584.

Thompson, J.D., Gibson, T.J., Plewniak, F., Jeanmougin, F. \& Higgins, D.G. (1997) The CLUSTAL_X windows interface: flexible strategies for multiple sequence alignment aided by quality analysis tools. Nucleic Acids Research, 25, 4876-4882.

Tickell, S.R. \& Parish, C.S.P. (1859) Itinerary, with memoranda, chiefly topographical and zoological through the southerly portions of the district of Amherst Province of Tennasserim. Journal of the Asiatic Society of Bengal, 24, 421-472.

Worthington Wilmer, J. \& Barratt, E. (1996) A non-lethal method of tissue sampling for genetic studies of chiropterans. Bat Research News, 37, 1-4.

Appendix Measurements taken from voucher specimens.

$F A$, Forearm length, from the extremity of the elbow to the extremity of the carpus with the wings folded. $I I I^{m}$, $I V^{m}, V^{m}$, Metacarpal length, from the extremity of the carpus to the distal extremity of the third, fourth and fifth metacarpals respectively. $I I I^{1}, I V^{1}$, First phalanx length, from the proximal to the distal extremity of the first phalanx of the third and fourth digits respectively. $I I I^{2}, I V^{2}$, Second phalanx length, from the proximal to the distal extremity of the second phalanx of the third and fourth digits respectively. TIBIA, Tibia length, from the knee joint to the ankle. $H F$, Foot length, from the extremity of the heel behind the os calcis to the extremity of the longest digit, including the claws. E, Ear length, from the lower border of the external auditory meatus to the tip of the pinna. MASS, Body mass taken using a 10 g Pesola scale. GTL, Greatest length of skull, the greatest antero-posterior length of the skull, taken from the most projecting point at each extremity. CCL, Condylo-canine length, from an exoccipital condyle to the alveolus of the anterior canine. $Z B, Z y g o m a t i c$ breadth, the greatest width of the skull across the zygomatic arches. $B B$, Breadth of braincase, greatest width of the braincase at the posterior roots of the zygomatic arches. $\mathrm{BH}$, Height of braincase, from the midpoint of exoccipital condyle to a point on the parietal vertically above it. $P C$, Postorbital constriction, the narrowest width across the constriction posterior to the orbits. TBL, Tympanic bulla length, greatest oblique antero-posterior diameter from the apex of the tympanic bulla internal to the hamular process to the most posterior part of the mastoid chamber of the tympanic bulla external to the base of the paroccipital process. TBW, Tympanic bulla width, taken across the bulla at the widest point perpendicular to the line of the antero-posterior diameter. $B W$, Basioccipital width, taken at the narrowest point between the two cochlea. $C-M^{3}$, Maxillary toothrow length, from the front of the upper canine to the back of the crown of the third upper molar. $M^{3}-M^{3}$, Posterior palatal width taken across the outer borders of the third upper molars. $C^{1}-C^{1}$, Anterior palatal width, taken across the outer borders of the upper canines. $C-M_{3}$, Mandibular toothrow length, from the front of the lower canine to the back of the crown of the third lower molar. $M D L$, Mandible length, from the most posterior part of the condyle to the most anterior part of the mandible.

\section{Biographical sketches}

Maria João Ramos Pereira and Hugo Rebelo are studying aspects of bat population genetics, habitat selection and roosting ecology.

Emma Teeling has a long-standing interest in bat systematics, evolution, conservation and the molecular process governing sensory perception and speciation.

Stephen J. O'Brien's principal research focus involves complex and multi-factorial disease gene discovery in infectious diseases. He has a secondary research interest in mammalian comparative genomics.

Iain Mackie, Si Si Hla Bu, Khin Maung Swe, Khin Mie Mie and Paul Bates have spent the last 5 years conducting bat research in Myanmar, with particular interest in acoustics, taxonomy and conservation. 